\title{
Brincando e compartilhando experiências com Narizinho e Pedrinho
}

\author{
Marcela Carolina Zen de Andrade \\ Mara Fernandes \\ Orientação: Adilson de Ângelo
}

\section{Caracterização da turma}

Nosso primeiro contanto com as crianças do maternal I no ano de 2008, aconteceu de forma sutil, como observadoras das relações e vivências ocorridas neste grupo. Nesse período de observação foi possível conhecer um pouco de cada criança, seus gostos, suas necessidades, ansiedades, desejos, formas de manifestações, as diferentes linguagens dentre outras coisas.

O maternal I possui quinze crianças matriculadas, sendo oito meninos e sete meninas, com idades de 2 anos e meio a 3 anos. Como podemos perceber, é uma turma mista com meninos e meninas, cada um com sua singularidade e sua característica, contribuindo para a história desta turma. A professora responsável por eles é Luciana, a auxiliar chama-se Lílian, a auxiliar responsável por acompanhar o Eduardo (criança com paralisia cerebral) chama-se Gisa.

Algumas crianças já utilizavam a fala como um meio para se comunicar com os demais, porém algumas ainda não desenvolveram totalmente esta linguagem. Cinco crianças ainda utilizavam fraldas, o Gustavo, a Eduarda, o Kauan, a Nicoly e o Eduardo, as demais já iam ao banheiro e controlavam seus esfíncteres.

Uma característica desta turma era a presença dos pais (pai e mãe) no cotidiano da creche. Era muito comum pais e mães chegarem e ficarem brincando com as crianças, participar das diversas situações e vivências por que passavam durante a tarde, a presença deles era freqüente, por isso não interferia na rotina da turma.

Revista eletrônica Zero-a-Seis - $\mathrm{n}^{\circ}$ 22. jun./dez. 2010

Núcleo de Estudos e Pesquisas da Educação na Pequena Infância - CED/UFSC 
Fomos bem acolhidas tanto pelas crianças e pelos pais, quanto pelas educadoras que sempre se colocaram à disposição para estarem nos auxiliando e contribuindo com a nossa formação.

\subsection{Apresentação das crianças}

\section{Apresentação das crianças do maternal II}

Ana Clara : Uma criança muito curiosa e atenta a tudo, não falava muitas palavras, mas se comunicava com gestos e olhares, possui um sorriso contagiante. Brigava pelas coisas que queria. Muito atenciosa com Eduardo, e conosco. Adorava mexer em objetos novos que trazíamos para sala, assim como em nosso cabelo, nossa bolsa, cadernos e canetas. Participava com muito entusiasmo de tudo que era proposto, porém não tinha paciência para esperar "a sua vez".

Eduarda: Durante as observações percebemos que geralmente ficava quieta, brincava sozinha e falava pouco. Chamava todas as educadoras de mãe. Porém, durante nossa intervenção logo aprendeu a pronunciar o nosso nome, conversava conosco em diversos momentos. Pronunciava muito bem cada palavra. Participava de todos os momentos propostos, mas quando era necessário terminar algo, ou dar a vez para o colega ela chorava, e algumas vezes mordia. Quando mordia alguma criança que não víamos, vinha nos contar. Era a menina que tinha os cílios iguais o da Emília.

Eduardo: Menino com um sorriso encantador, um olhar que cativava qualquer um que se aproximasse dele. Possui algumas dificuldades por ter paralisia cerebral. Participava de todos os momentos, muitas vezes seus colegas o ajudavam, era muito querido por todos. Brincar com a massinha foi um dos momentos em que "Dudu" mais se divertiu. No parque sorria para todos, adorava "caminhar" na calçada e sentar na areia para brincar.

Revista eletrônica Zero-a-Seis - $\mathrm{n}^{\circ}$ 22. jun./dez. 2010

Núcleo de Estudos e Pesquisas da Educação na Pequena Infância - CED/UFSC 
Érica: Muito simpática, sempre que chegávamos vinha nos beijar. Brincava muito com suas amigas Gabriela e Nicoly, carregando bonecas de um lado para o outro. Participava de tudo que era proposto. No dia em que fomos no cestão do povo fez a maior festa nos ajudando a escolhermos as frutas para a deliciosa salada de fruta.

Felipe era o nosso ajudante, tudo que fazíamos queria ajudar (arrumar a sala, carregar cadeiras, pegar tintas, lavar frutas...). Conversava muito, porém não gostava de dividir a nossa atenção com outras crianças. Adorava brincar de carro, para ele o cavalo, o tubarão, a gangorra, o pneu, tudo era o carro. Não gostava muito de emprestar os brinquedos. Participava de todas as atividades. Era muito carinhoso conosco. No dia da salada de fruta ele foi uma das crianças que mais ajudou, lavou as frutas, cortou, serviu e comeu bastante. No refeitório servia-se sempre sem auxílio e comia muito bem, adorava encontrar sua irmã na hora das refeições. Era amigão do Miguel.

Gabriela no início parecia muito tímida, porém logo foi se soltando, e ficando mais a vontade conosco. Gostava muito de brincar com Nicoli e Érica. Conversa bastante com todos. Era comum ver Gabriela e Nicoli de mãos dadas, e sempre brincando com as bonecas.

Gustavo falava poucas palavras mas se comunicava muito bem. Gostava muito de correr, de jogar bola e de empurrar o carrinho do "Dudu". Nas experiências propostas por nós durante o estágio ele sempre participava. Adorava se lambuzar de tinta. Não gostava de dividir os brinquedos com os amigos, quando queria algo que estava com outra pessoa puxava da mão do outro e mordia. Porém, aos poucos começou a se relacionar de formas diferentes com os colegas, pedia emprestado, esperava sua hora, e quando batia ou mordia alguém abraçava e beijava depois, com nossa mediação.

Kauan era um dos menores da turma. E sempre bem "ligeiro", corria sempre de um lado para o outro. Falava pouquíssimo. Adorava brincar com o lego, fazia sempre trenzinho com 
as peças. Não tinha muita paciência para escutar uma história ou para assistir a um filme. Quando batia em algum colega tampava o rosto e abaixava a cabeça. Seus pais iam constantemente no período da tarde brincar com ele na creche. Era comum vê-lo sorrindo. Adorava ir ao parque. Sempre antes de ir embora se despedia de nós com um beijo.

Maria Eduarda quieta e observadora. Adorava a caixa surpresa, sempre que levávamos, ela ficava bem animada e tentava adivinhar o que tinha dentro da caixa. Adorava brincar com as bonecas e folhear os livros.

Miguel foi o primeiro que nos acolheu. Fazia diversas perguntas, apresentou-nos a todos, mostrou a creche, e sempre nos explicava tudo. Convidava-nos para ir com eles aos diversos locais, oferecia lanche e sempre queria que sentássemos na mesma mesa que ele na hora do refeitório. Pedia para ir para nossa casa, e adorava a Cuca, era comum ver o menino com um lençol na cabeça dizendo que era a Cuca. Costumava brincar com o "Lipe" e com o "Dudu". Imitava-nos em tudo, até mesmo na forma de contar histórias.

Nicoly uma menina muito alegre, com um sorriso contagiante. Envolvia-se com facilidade nas brincadeiras proposta juntamente com seus amigos. Quando gostava do que estava fazendo, não queria mais parar. Adorava mexer em nossos materiais, principalmente na máquina fotográfica. Sempre pedia para nós batermos uma foto dela e logo em seguida queria olhar. Não podia ver a máquina que já estava dando um lindo sorriso.

Nicolas, um menino muito carinhoso. Gostava de participar de todas as propostas feitas. Brincar com a massinha foi um dos momentos em que ele mais participou. Fazia diversas formas, ora dizia que a minhoca, ora o jacaré. Adorava esconder os brinquedos que mais gostava de brincar. Às vezes estava meio incomodado e não queria brincar com ninguém.

Pedro era o "chará" do Pedrinho (personagem do sítio). Participava de tudo, adorava ir ao parque e brincar com Nicolas. Falava poucas palavras e era uma criança quieta. Porém,

Revista eletrônica Zero-a-Seis - nº 22. jun./dez. 2010

Núcleo de Estudos e Pesquisas da Educação na Pequena Infância - CED/UFSC 
quando sugeríamos alguma experiência que ele gostava, éramos presenteadas com as gargalhadas gostosas de Pedro. Sempre que falávamos na Cuca, ele parava o que estava fazendo e nos olhava arregalado. Quando viu a Cuca na televisão se escondeu atrás das almofadas.

Roger, pouco conhecemos e convivemos com este menino, pois ele quase não estava presente. Quando vinha se mostrava uma criança calma e bastante quieta. Adorava brincar no parque junto com seus amigos

\section{Justificativa}

O tema de nosso projeto: "Brincando e compartilhando experiências com Narizinho e Pedrinho", foi pensado de acordo com a proposta feita pela professora da turma, Luciana, em realizarmos um projeto que viesse de encontro ao que estava sendo desenvolvido por ela até então, sobre o Sitio do Pica-pau amarelo. Dessa forma, não haveria uma ruptura ao que já estava sendo desenvolvido por aquelas educadoras com as crianças.

Nas observações, percebemos o quanto à brincadeira estava presente no dia-a-dia daquela turma, na maioria das vezes estavam brincando e qualquer elemento para eles poderia servir como brinquedo. Porém, na sala não havia muitas opções de brinquedos, fazendo com que em determinadas situações houvesse conflitos, e as brincadeiras normalmente eram as mesmas. Quando brincávamos com eles, e trazíamos um elemento novo, eles se instigavam ainda mais a brincadeira.

De acordo com o documento publicado pelo MEC intitulado: Critérios para um Atendimento em Creches que respeite os direitos fundamentais das crianças em 1995, a brincadeira é um dos direitos das crianças e respeitar e garantir os direitos das crianças foi um dos objetivos de nosso projeto.

Durante as primeiras semanas, em que observamos, vimos que as crianças

Revista eletrônica Zero-a-Seis - $\mathrm{n}^{\circ}$ 22. jun./dez. 2010

Núcleo de Estudos e Pesquisas da Educação na Pequena Infância - CED/UFSC 
conheciam apenas alguns personagens do Sítio, e a que mais reconheciam era a Emília, por isso trouxemos como proposta o tema "Brincado e compartilhando Experiências com Narizinho e Pedrinho".

Entendemos que é dever da Educação Infantil permitir a ampliação dos conhecimentos das crianças, partindo desse pressuposto é necessário considerarmos o que elas conhecem o que elas trazem consigo, mas também permitir o contato com outras culturas, com diversos tipos de música, de materiais, o contato com revistas, livros, diferentes brinquedos, filmes, tintas, argila, papéis com diferentes texturas, instigando a fantasia e a curiosidade. De acordo com isto Tristão afirma:

Muitas das experiências vividas pelas crianças no contexto da creche partirão de uma proposta das professoras ou de uma permissão destas para que os pequenos experimentem, provem, saboreiem, sintam. Dessa forma é fundamental que estas profissionais planejem muitas possibilidades para as crianças experimentarem. (Tristão, 2004, p. 147).

Partindo deste pressuposto, acreditamos ser de extrema importância essa consciência por parte dos educadores. Desta forma durante nossa regência na creche procuramos na medida do possível focar o nosso olhar também para essa questão proporcionando para os pequeninos, momentos em que eles pudessem ampliar seus conhecimentos através da experimentação, fazendo-as de diferentes formas, proporcionando uma ampliação contínua de seus conhecimentos, fomentando na criança esse interesse em estar aberto ao novo. Planejamos os momentos que muitas vezes passam a ser somente rotina das creches, como, por exemplo, os momentos de troca, higiene, refeição e o parque.

Procuramos planejar de acordo com o que Ostetto (2000) afirma:

O planejamento compreendido na ação: prever, fazer, registrar, avaliar, para então seguir planejando- replanejando de acordo com o movimento, os desejos e as necessidades do grupo. O planejamento compreendendo a atitude de cada educador diante de sua prática.

Planejamos todos os momentos desta forma, estando atentas as necessidades das

Revista eletrônica Zero-a-Seis - $\mathrm{n}^{\circ}$ 22. jun./dez. 2010

Núcleo de Estudos e Pesquisas da Educação na Pequena Infância - CED/UFSC 
crianças, e as suas manifestações para que pudéssemos propor momentos significativos a aprendizagem das crianças.

Buscamos explorar de diferentes formas os espaços na creche, o parque, o refeitório a brinquedoteca, a sala, para que estes espaços fossem significativos e contribuíssem para o desenvolvimento e socialização das crianças, promovendo e estimulando a brincadeira.

\section{Brincando compartilhando experiências ...}

As atividades realizadas durante este projeto foram: pinturas, confecção de almofadas, de móbiles, saída de campo (Cestão do Povo), contação de história, massinha, culinária, músicas, expressão corporal, com elas, intentamos trabalhar o incentivo à socialização, a identidade e a importância de cada um, o trabalho em grupo, a exploração e apropriação de diferentes espaços, entre outros.

Iniciamos com uma proposta de mudança no espaço da sala em que as crianças do maternal I permaneciam grande parte do dia. Propusemos às educadoras, algumas mudanças, uma reorganização naquele espaço, pois durante nossas observações percebemos que ali havia objetos que poderiam ser mais explorados pelas crianças, se estivessem em um outro local da sala. Para nossa surpresa, no dia em que iniciamos nossa intervenção o espaço já tinha sido modificado, as educadoras acolheram nossa sugestão e elas mesmo efetuaram a mudança.

Essa nossa proposta de reorganização daquele espaço vem de encontro com o que Guimarães (1999, p.13) afirma que o "ambiente é organizado pelo adulto a partir do conhecimento que tem das crianças", neste caso propusemos de acordo com o que pudemos conhecer das crianças daquele grupo através das observações.

$\mathrm{Na}$ sala, a casinha do Sítio do Pica-Pau Amarelo, feita com caixas de leite, primeiramente ficava num canto entre a estante e a parede, ou seja, as janelas da casa não tinham como ser utilizadas, pois uma ficava encostada na parede e a outra na estante. Nessa nova organização do espaço as crianças conseguiam explorar mais esta casa, podiam espiar os amigos pela janela, e até mesmo entrar e sair por elas.

Revista eletrônica Zero-a-Seis - $\mathrm{n}^{\circ}$ 22. jun./dez. 2010

Núcleo de Estudos e Pesquisas da Educação na Pequena Infância - CED/UFSC 
Ressaltamos a importância do espaço em uma instituição de educação infantil ser pensado conforme as necessidades das crianças que o ocupam. Por isso concordamos com Carvalho (1994) que afirma:

Qualquer ambiente construído exerce um impacto tanto direto como indireto, ou simbólico, sobre os indivíduos. Na primeira instância, fatores físicos podem influenciar o comportamento, facilitando certas atividades e obstruindo outras. (Carvalho 1994, p.108)

A oportunidade para explorar ambientes ricos e variados geralmente está associada ao desenvolvimento cognitivo, social e motor. As características de complexibilidade e variedade dos objetos inanimados têm sido relacionadas ao desenvolvimento. (...) Os ambientes devem fornecer oportunidades para as crianças andarem, correrem subirem, descerem e pularem com segurança, permitindo-lhes tentar, falhar e tentar novamente. (Carvalho, 1994, p.110)

A reorganização do espaço sempre exerce uma mudança, uma reação nos indivíduos que ali interagem. Podemos, vivenciar isso com esta turma de 15 crianças, que entravam e saiam da casinha como se fosse um elemento novo naquele espaço.

Repensando ainda a constituição daquele espaço, Emília (personagem de Monteiro Lobato) presenteou as crianças com um minhocão (uma almofada comprida em forma de minhoca, com olhos e boca) sendo este mais um elemento na sala.

Convidamos as crianças para sentarem no tapete, pois queríamos conversar. Elas largam tudo e foram correndo, como normalmente faziam.

- Gente, eu encontrei a Emília quando estava vindo e ela me disse que vai mandar um presente para nós sabia? Um presente lá do sítio para ficar aqui na nossa sala, o que será que é? (Marcela)

- Um bicho. (Nicolas)

- Um bicho? Será que é um bicho? Ela me contou que já tinha trago este presente aqui para a creche, onde será que ele ta? Será que ela escondeu?

Miguel e Nicolas ficaram olhando para todos os cantos da sala, como se estivessem procurando.

- Não ta. (Miguel)

- A Emília contou que é bem pesado esse presente, só quem comeu tudo no lanche, que está forte é que vai conseguir carregar. Eu não comi no lanche to fraquinha, vocês vão ter que me ajudar. Quem vai me ajudar? (Marcela )

Todas as crianças diziam "eu,eu". Nicolas levantou a blusa para mostrar que tinha comido tudo e estava forte.

- Você comeu tudo Nic, está forte? Que bom, então vai conseguir me ajudar.

Revista eletrônica Zero-a-Seis - $\mathrm{n}^{\circ}$ 22. jun./dez. 2010

Núcleo de Estudos e Pesquisas da Educação na Pequena Infância - CED/UFSC 
$\mathrm{Na}$ seqüência outras crianças também levantaram a blusa mostrando que estavam forte.

- Bom, eu acho que deve estar lá na rua, vamos procurar?

As crianças logo levantaram para procurar, quando saímos da sala encontramos um "minhocão" no corredor, (já colocado por nós anteriormente).

- Olha só gente, a Emília nos deu um minhocão. Viram que grande que é essa minhoca?

As crianças sorriam, Nicoli logo pulou em cima da minhoca, Kauan deitou no chão com a cabeça em cima, Miguel e Érica subiam e desciam da minhoca, os demais olhavam surpresos.

- E agora, onde vamos colocar o nosso minhocão?

- Aqui. (Lipe apontando para a sala)

- Na sala Lipe? Mas como nós vamos carregar?

- Assim ó. (Miguel tentou levantar, mas como era pesado não conseguia carregar sozinho).

- Todo mundo tem que ajudar né Miguel? Senão não vai dar. Vamos ajudar o

Miguel galera.

Todos foram ajudar a carregar, uns tropeçavam e caiam, fazendo com que a minhoca também caísse. Porém, logo já se ajudavam a levantar. Com o auxílio das crianças colocamos a minhoca em cima do tapete próximo a parede da janela e do mural. (Registro do dia 28/05/08)

O minhocão foi acolhido com muito carinho pela turma, o fascínio por ser um presente dado pela Emília, por ser um elemento novo naquele espaço, era notório ao observar aquelas crianças. Neste episódio destacado, poderíamos analisar diversos aspectos, como a curiosidade, ao tentarem descobrir que presente Emília tinha mandado para aquela turma, ao olharem pelos cantos da sala tentando procurar; o estímulo à linguagem e a comunicação, ao incentivar as crianças a falarem, a se manifestarem, valorizando as coisas que diziam no momento da conversa; a imaginação, no momento em que imaginavam as nossas conversas com a Emília e o presente que ela havia mandado; a participação das crianças, desde o momento da conversa até ajudarem a carregar o presente e a escolherem o local que seria colocado; as relações estabelecidas, a ajuda mútua, o carinho, as risadas compartilhadas, entre outras coisas.

No entanto, ressaltamos neste momento a importância da participação das crianças na construção daquele espaço, no ambiente que deve ser organizado sempre pensando em suas necessidades e especificidades.

Quando as crianças foram questionadas por nós sobre o local que gostariam de colocar o presente, Felipe logo sugeriu que levássemos para a sala, em seguida Miguel já indicou como deveríamos fazer para levar, e todos auxiliaram e acolheram a sugestão dos colegas, ajudando a carregar e arrumando o local.

Revista eletrônica Zero-a-Seis - $\mathrm{n}^{\circ}$ 22. jun./dez. 2010

Núcleo de Estudos e Pesquisas da Educação na Pequena Infância - CED/UFSC 
O "minhocão" não foi feito por elas, mas o uso, a apropriação e a escolha do lugar que este ocupou, foi uma escolha das crianças. Desta forma, aquele espaço tornou-se um ambiente significativo para elas. "O espaço de serviço voltado pra as crianças traduz a cultura da infância, a imagem da criança, dos adultos que o organizaram; é uma mensagem do projeto educativo concebido para aquele grupo de crianças". (Gallardini, 1996b:8 apud Guimarães)

Todo o dia no horário que as crianças dormiam, o minhocão era retirado daquele lugar, geralmente colocado pelas educadoras em cima da casinha. Quando chegávamos, a maioria das crianças já estava acordada e logo, algumas delas, como Miguel, Felipe e Nicolas, nos mostravam que o minhocão não estava no lugar e pediam nosso auxílio para arrumar aquele espaço.

Assim, aos poucos, fomos reorganizando e criando um novo espaço naquele ambiente, com o auxílio das crianças, fazendo com que elas participassem de cada momento trazendo sugestões e incorporando aquelas mudanças.

Sempre que conversávamos e contávamos histórias, nos reuníamos neste "cantinho", sentados no minhocão e no tapete. Foi aí que contamos a história da lagarta que vira borboleta, com um livro bem ilustrado que chamava atenção das crianças. Após, contarmos a história propusemos às crianças a construção de um varal com livros, que ficariam expostos para que sempre que desejassem ter livre acesso. Pois, até então estes livros ficavam guardados em caixas, fora do alcance das crianças.

Nosso objetivo era fazer com que este "cantinho" aproximasse as crianças dos livros, este passa a ser não só um texto mas também um objeto que possui suas próprias características, fazendo com que as crianças se relacionassem com os livros de uma forma física. Neste caso, "o canto da leitura torna-se o lugar onde o conteúdo é fascinante. O fato de que a criança pode fantasiar faz de qualquer lugar um lugar onde o conteúdo é fascinante". (Mello, 2007, p.14)

As crianças gostaram da idéia, mas algumas ficavam olhando, sem entender ao certo como funcionaria. Então, amarramos um barbante fazendo um varal, e convidamos as crianças a ajudarem a colocar os livros pendurados. Demonstramos como elas poderiam fazer para colocar, porém algumas não conseguiam, então auxiliamos. Todas as crianças nos ajudaram a colocar os livros, após este momento, as incentivamos a folhearem os livros e a explorarem aquele espaço que tinham ajudado a construir. Algumas crianças brincavam,

Revista eletrônica Zero-a-Seis - $\mathrm{n}^{\circ}$ 22. jun./dez. 2010

Núcleo de Estudos e Pesquisas da Educação na Pequena Infância - CED/UFSC 
tirando e colocando os livros pendurados, diversas vezes, colocavam com a capa para frente, depois ao contrário e nos chamavam para ajudar quando não conseguiam. Outras ficaram folheando e observando os livros sentadas no minhocão.

O cantinho da leitura, como espaço pensado e estruturado dentro da sala, possibilita à criança a liberdade de escolher um livro para olhar, folhear, brincar, a hora que desejar. "O importante é que neste canto da leitura , a criança entra em contato com os livros em lugares onde ela se sente à vontade e pode se instalar com conforto" (Mello, 2007).

Explorar outros espaços da creche também foram momentos significativos da nossa experiência com essas crianças. A creche Irmão Celso, possui um espaço externo bem amplo, porém as crianças do berçário II e do maternal I e II costumam freqüentar apenas o "parque dos pequenos" (forma como eles chamam), as outras turmas ocupam o "parque grande" um espaço com mais variedades de brinquedos, e mais amplo, com acesso à horta, com árvores e uma área com gramado.

No dia em que levamos as crianças do maternal I para este outro espaço (parque grande), elas corriam de um lado para o outro, brincavam nas gangorras, na casinha, nos balanços de pneu, nas árvores. Levamos as crianças em um momento que tinha apenas uma outra turma neste espaço.

Conseguimos perceber a importância de explorar todos os espaços que a creche oferece oportunizando para criança diferentes vivências, relações, desafios, sensações.

(...) Ao terminarem de comer, levamos as crianças para o parque "grande", eles corriam de um lado para o outro rindo, não sabiam nem onde brincar. Felipe foi logo para a gangorra, brinquei um pouco com ele, eu sentada de um lado e ele do outro, o menino dava risadas. Depois, convidei o Nicolas que estava próximo nos olhando para sentar no meu lugar, ele aceitou. Os dois ficavam sentados, mas não impulsionavam a gangorra com os pés para que pudessem subir e descer. Expliquei que deviam empurrar o pé no chão para a gangorra subir, então começaram a brincar, e davam risadas, as vezes Nicolas esquecia de empurrar, então Felipe ficava no alto, dando várias risadas. (...)

Revista eletrônica Zero-a-Seis - $\mathrm{n}^{\circ}$ 22. jun./dez. 2010

Núcleo de Estudos e Pesquisas da Educação na Pequena Infância - CED/UFSC 
(...) Eduarda e Stéfani ficaram um tempão brincando no balanço de pneu, a Eduarda sentada e a Stéfani empurrando. Kauan e Nicoli subiam e desciam o brinquedo que dava acesso ao escorregador, Nicoli subia pelas cordas. Kauan ao subir uma dessas vezes caiu entre um degrau e outro da escada e chorou bastante, mas logo voltou a brincar. Felipe depois de brincar diversas vezes na gangorra, pediu um pneu. Mara foi procurar e encontrou, trouxe para ele. $\mathrm{O}$ menino corria de um lado para o outro empurrando o pneu, subia as escadas, e quando chegava lá em cima empurrava o pneu e descia bem rápido para pegar novamente com receio de que alguém pegasse o pneu. Algumas crianças maiores que estavam brincando no parque ficaram auxiliando as crianças do maternal, ajudavam a colocar os pequenos nos balanços, a subir as escadas, entre outras coisas. (...)

(...) Ana, Miguel, Felipe e Nicolas estavam tentando subir toda hora, porém os maiores não deixavam, depois de um tempo eu subi e logo vieram atrás, então fui com eles onde tanto queriam, lá em cima, na horta, na grama. Eles corriam um atrás do outro, alguns ficaram mexendo nas garrafas pet's. Felipe subiu com o pneu, empurrava para todos os lados, depois de brincarem um pouco lá em cima, convidei para descermos e eles foram correndo na minha frente. Miguel Ana e Nicolas, ao invés de descerem as escadas foram em direção a "gruta", entraram e sentaram no local onde seria para estar alguma imagem. Os 3 ficaram ali sentados rindo, depois saíram para voltarmos para sala. (Registro do dia 13.05)

Estes foram apenas alguns registros das situações ocorridas neste dia no parque, no espaço que essas crianças não costumavam ocupar. Conseguimos evidenciar a importância de explorarmos os diversos ambientes oferecidos pela creche.

Neste dia, as crianças exploraram o seu corpo, os diversos movimentos: pular, correr, se embalar, subir e descer escadas, se mover ao brincar na gangorra, escorregar, etc.

A sensação do "aqui não pode", estimulava Ana Clara a subir as escadas para ir até a horta, porém as crianças maiores impediam o acesso. Como mostra na figura:

As relações das crianças com seus pares aconteceram de forma intensa, fazendo com que produzissem sua cultura infantil. O espaço desafiava as crianças, algumas aprenderam neste dia a brincar na gangorra, a perceber que tinham que impulsionar-se com os pés no chão para que a gangorra subisse e descesse, quando não conseguiam algum colega se aproximava e empurrava, auxiliando-os. Assim como no balanço, Eduarda não

Revista eletrônica Zero-a-Seis - nº 22. jun./dez. 2010

Núcleo de Estudos e Pesquisas da Educação na Pequena Infância - CED/UFSC 
conseguia se embalar, mas isso não impediu que ela brincasse, pois sua amiga Stéfani a empurrou.

Concordamos com Carvalho (1994, p.117) quando afirma que em sua concepção:

a criança, participa ativamente em seu desenvolvimento através de suas relações com o ambiente, especialmente pelas suas interações com adultos e demais crianças (coetâneas ou mais velhas), dentro de um contexto sócio-histórico específico. Ela explora, descobre e inicia laços em seu ambiente; seleciona parceiros, objetos, equipamentos e áreas para a realização de atividades, mudando o ambiente através de seus comportamentos. Entretanto, por outro lado, é necessário salientar que os comportamentos infantis são influenciados pelo ambiente fornecido pelos adultos de acordo com seus objetivos pessoais, construídos com base em suas expectativas culturais relativas aos comportamentos e desenvolvimento infantis.

Notamos que as crianças se desenvolvem participando deste processo, também por meio das relações sociais que estabelecem no ambiente da creche, com seus pares e com os profissionais desta instituição. Nas diversas experiências que tivemos durante o estágio percebemos que o ambiente instiga e influencia o comportamento das crianças, suas escolhas, seu desenvolvimento, seus movimentos, sua imaginação e suas interações com as outras pessoas.

\section{1 ... com Narizinho e Pedrinho}

Um dos aspectos que nos chamou atenção, foi como as crianças estavam atentas a tudo o que trazíamos de novo a elas e a receptividade com que elas acolheram ao projeto. Percebemos que as crianças acolheram tanto os objetos novos que trouxemos, como também se apropriaram naturalmente da nossa idéia inicial do projeto.

Durante todas as nossas propostas percebíamos que as crianças participavam com intensidade, porém sempre respeitávamos o tempo de cada uma, pois sabemos que elas são diferentes e possuem cada qual o seu tempo, o seu ritmo. Quando pintavam, passavam alguns minutos entretidos e logo já lavavam as mãos para brincar com outra coisa; outras não queriam ir embora porque queriam continuar pintando, outras ainda queriam nos ajudar a fazer a salada de fruta, e outras queriam brincar pela sala.

Revista eletrônica Zero-a-Seis - nº 22. jun./dez. 2010

Núcleo de Estudos e Pesquisas da Educação na Pequena Infância - CED/UFSC 
Instigar a curiosidade das crianças foi um dos aspectos que mais procuramos trabalhar durante o estágio, desde o primeiro dia. Usávamos muitas vezes a caixa surpresa para instigar as crianças a imaginarem o que poderia ter dentro. Para ilustrar este momento destacamos esta cena:

Contamos as crianças que Dona Benta tinha mandado uma caixa para entregarmos a eles, porém tínhamos que adivinhar o que tinha dentro. As crianças tentavam adivinhar o que tinha na caixa. Nicolas repetia diversas vezes, tentado adivinhar, dizia "é o bicho", Érica dizia que era o peixe.

Quando a caixa chegou algumas crianças tentaram levantar, mas pedimos que se sentassem. A professora, a Lílian, e o Luciano estavam sentados no tapete com as crianças.

- Vamos sacudir a caixa? Será que faz barulho? (Marcela)

Ao sacudir não fez nenhum barulho. Então Felipe falou:

- Não tem nada.

- Será Lipe? Será que a dona Benta mandou a caixa vazia? (Marcela)

- É. ( Miguel)

- Poxa, mas aí eu vou ficar triste. Eu acho que ela mandou alguma coisa do sítio.

- A coba. ( Nicolas)

- A cobra? Será? (Marcela)

Então, Marcela chamou as crianças uma de cada vez para espiar o que tinha na caixa. Maria Eduarda fazia força para abrir a caixa, estava agoniada querendo ver, primeiro Marcela colocou um bracinho da Narizinho para fora e pedia para eles dizerem o que tinha ali, em seguida ela foi mostrando outras partes do corpo da boneca. Então Gabriela disse:

- Uma boneca.

- Será Gabi?

A menina afirmava com a cabeça.

Quando Marcela tirou a Narizinho da caixa, a maioria das crianças sorriu, Ana Clara e Nicoli batiam palmas, Miguel foi abrir a caixa para ver se tinha mais alguma coisa. Nicolas berrou:

- O bicho, o bicho.

- É um bicho, Nic?

- é.

- Não Nicolas, é a Narizinho, a amiga da Emília.

- Naizinho? ( falou e colocou o dedo no nariz dele).

As crianças davam oi para a Narizinho, Eduarda, Nicoli, Lipe, levantaram para dar um beijo na nova amiga da sala, Ana Clara levantou e foi abraçá-la.

( Registro do dia;;;)

$\mathrm{Na}$ cena ao trazermos a caixa com um elemento surpresa escondido, buscamos estimular a imaginação, a curiosidade, e a linguagem de cada uma daquelas crianças. Miguel, Felipe, Nicolas e Gabriela tentavam adivinhar o que tinha na caixa, enquanto

Revista eletrônica Zero-a-Seis - $\mathrm{n}^{\circ}$ 22. jun./dez. 2010

Núcleo de Estudos e Pesquisas da Educação na Pequena Infância - CED/UFSC 
outros ficavam atentos. Quando Narizinho saiu da caixa, algumas crianças ficaram supresas, Nicolas continuou dizendo que era o "bicho", outras levantaram para tocar abraçar e beijar a boneca de pano. Este momento, despertou nas crianças sentimentos diversos.

Estimular a curiosidade é algo que consideramos pertinente ao trabalho das educadoras com as crianças, pois, como afirma Pereira (2008), esta é a melhor forma de despertá-la ao saber. O papel do educador é questionar as crianças e ficar atento às suas respostas, fazendo uma ponte entre as colocações delas e o conhecimento, instigando a questionarem, a sempre querem saber mais, mantendo esta curiosidade.

Também argumentando sobre a importância da curiosidade, Paulo Freire nos diz que "o exercício da curiosidade convoca a imaginação, a intuição, as emoções, a capacidade de conjeturar, de comparar, na busca da perfilização do objeto ou do achado de sua razão de ser". (Freire 1996, p.88). Foi assim que, no contexto da nossa intervenção, Narizinho e Pedrinho estimularam muitos destes momentos, convidando às crianças a participarem, a ampliarem seu repertório cultural e a experimentarem diversas situações. No primeiro dia em que estes personagens chegaram na turma, já trouxeram a receita da massinha de modelar caseira para fazer com as crianças. Todas gostaram da idéia e logo se agitaram para ajudar a fazer. Levamos os ingredientes para fazermos a massinha com elas, ficavam ansiosas aguardando o momento em que ajudariam: uns colocaram farinha, outros o sal, a água e cada um mexeu um pouco a massinha. Falamos um pouco sobre cada um dos ingredientes, sobre a quantidade necessária, e deixamos as crianças se lambuzarem e experimentarem o "fazer a massinha".

Todos queriam mexer, amassar, Felipe logo começou a enroscar a massinha e dizer:

- Uma cobra.

Nicolas, fazia diversas formas diferentes com a massinha e sempre relacionava com algum bicho, em alguns momentos dizia que era o jacaré, depois dizia que era a minhoca, ou simplesmente o "bicho".

Conversamos com eles sobre as cores, alguns já conseguiam identificar algumas, porém outros trocavam os nomes a todo momento. Stéfani pegou um pouco de massinha e sentou em baixo da mesa. Kauan tentava comer, e o resto picava e jogava no chão. Demos um pouco de massinha, para o Eduardo, que tentava fazer diversos movimentos com a mão, apertava a massinha e olhava para a sua

Revista eletrônica Zero-a-Seis - $\mathrm{n}^{\circ}$ 22. jun./dez. 2010

Núcleo de Estudos e Pesquisas da Educação na Pequena Infância - CED/UFSC 
mão sorrindo. Neste momento sua mãe chegou, Eduardo se agitou no carrinho, ela demonstrou ficar bem contente em ver seu filho com a massinha, sentou em uma cadeira com as demais crianças e colocou o Eduardo em seu colo, incentivando o menino a mexer na massinha, batendo as mãos, amassando, fazendo diversos movimentos. Felipe e Nicolas foram as crianças que ficaram mais tempo entretidas com a massinha, deram várias formas a ela, e sempre nos chamavam para mostrar o que tinham feito. (Registro do dia 05/05/08)

Nesta experiência, as crianças tiveram a oportunidade de participar, desde o fazer até o brincar com a massinha. Felipe e Nicolas ao fazerem diversas formas com a massinha, manuseavam este material experimentando a sua textura característica, e ao mesmo tempo imaginavam, criavam personagens, e mostravam para os demais. Estimulávamos as crianças a fazerem diversas coisas e não somente a minhoca ou a cobra. Kauan experimentou literalmente a massinha, comendo, quando vimos não repreendemos o menino e sim explicamos o que ele poderia fazer, quantas coisas poderia criar com aquele material, e que não era comida. Respeitamos o tempo de cada criança brincar com a massinha, algumas logo se dispersaram e foram brincar com outros objetos dispostos pela sala, outras ficaram até o momento de írmos embora brincando com o que propusemos. Outro fato que nos chamou a atenção foi o do "Dudu", pois este foi um dos momentos em que ele mais participou, mexendo na massinha e tentando abrir e fechar os dedos (movimento que tem dificuldade de fazer), sorria e olhava para todas as crianças.Até mesmo a sua mãe ficou surpresa com a reação do menino neste momento.

Também pintamos almofadas, pedaços de papel cartão (com os quais fizemos móbiles), diversas experiências em que as crianças puderam experimentar, ter o contato com diversos tipos de materiais, possibilitando na criança diversas sensações. Ao pintarmos as almofadas permitimos que as crianças utilizassem os materiais da forma como desejassem, valorizando assim, suas expressões artísticas e culturais.

Revista eletrônica Zero-a-Seis - $\mathrm{n}^{\circ}$ 22. jun./dez. 2010

Núcleo de Estudos e Pesquisas da Educação na Pequena Infância - CED/UFSC 
Após terminarmos de organizar o local, pegamos o tecido e tintas para pintar. As crianças estavam todas ao redor esperando, alguns quando nos viram com a tinta guache e com os pincéis já começaram a erguer a blusa para não sujar.

Nicole não ergueu a blusa, então Marcela pediu que erguesse e que guardasse o bico, porém ela não quis. Colocamos os potes com tinta sobre a mesa ao alcance deles, assim como os pincéis, cada um pintava conforme queria (com os dedos ou com os pincéis), todas as crianças utilizaram os pincéis, mas algumas alternavam, hora pintavam com o pincel hora com os dedos. Os potes colocados sobre a mesa eram de uso coletivo, de vez em quanto trocávamos um pouco o local onde estavam os potes para que pudessem utilizar outras cores. (Registro do dia $06 / 05 / 08$ )

Conforme destacado na cena acima, deixamos as crianças livres para pintarem como quisessem, utilizando os pincéis ou as mãos, as diferentes cores disponíveis, valorizando assim, suas impressões, caracterizações, imaginação, entre outros. Buscamos principalmente envolver as crianças, ou seja, estimular nelas o interesse e a curiosidade de explorar os materiais disponíveis. Desta forma, buscamos fazer uma atividade diferente e que fosse de interesse das crianças, por isso propusemos que a pintura fosse feita no parque, ou seja, um local que geralmente eles estão acostumados a brincar somente. O objetivo era também deixar as crianças "livres" para pintarem da forma como quisessem, utilizando o pincel, as mãos, os braços, enfim, que pudessem expressar-se livremente.

Nestes momentos procurávamos aguçar também a imaginação das crianças. Constantemente percebíamos que a imaginação estava presente nas mais diversas atividades desenvolvidas pelas crianças em todos os momentos.

Segundo Vigotisky:

A imaginação é um processo psicológico novo para a criança; representa uma forma especificamente humana de atividade consciente, não está presente na consciência de crianças muito pequenas e está totalmente ausente de animais. Como todas as funções da consciência ela surge originalmente da ação. (Vigotisky,1984, p.208)

Como afirma o teórico, a imaginação surge da ação, por isso propusemos às crianças diversos momentos em que essa imaginação pudesse ser estimulada, como ao manusear a massinha, ao brincar com os personagens do sítio, pintar almofadas, brincar, ir ao cestão do povo, entre outras coisas.

Revista eletrônica Zero-a-Seis - $\mathrm{n}^{\circ}$ 22. jun./dez. 2010

Núcleo de Estudos e Pesquisas da Educação na Pequena Infância - CED/UFSC 
Porém discordamos do autor, quando afirma que a imaginação está ausente nas crianças muito pequenas, pois desde quando estas crianças estavam no berçário II já observávamos atitudes em que as crianças imaginavam, ressignificavam objetos, criavam e recriavam.

\section{“Cuidado com a Cuca que a Cuca te pega"...}

Um dos personagens do Sítio do Pica-Pau Amarelo por quem as crianças tinham um fascínio era a Cuca, que era muito temida pelas crianças, mas ao mesmo tempo em que era muito querida por elas. Despertava medos e curiosidades na turma. Em vários momentos nos deparávamos com uma criança, geralmente o Miguel ou o Felipe, com um pano na cabeça assustando os colegas, dizendo ser a "Cuca". Felipe sempre saía com o lençol na cabeça assustando os colegas e pedia para colocarmos a música da Cuca.

Quando começava a música Pedro sempre ficava com expressão de preocupação, assustado, escutando atentamente, tinha medo quando seus amigos vinham "vestidos" de Cuca assustá-lo. Atentas a isso, planejamos um dia em que a "Cuca" em forma de fantoche grande, aparecesse para visitar as crianças. Neste dia levamos todos para brincarem na brinquedoteca e lá a Cuca apareceu, de forma inusitada: estava escondida atrás da cortina e colocou apenas a cabeça para fora.

- Mais que barulho. Quem está fazendo essa bagunça na minha casa? (cuca)

As crianças no primeiro momento se assustaram e alguns se aproximaram para ver o que era.

- A cuca. (Algumas falaram).

- Oi quem são vocês? (Cuca)

- Meu nome é Miguel.(Miguel)

- Oi Miguel, que bagunça é essa? (Cuca)

Nesse momento o Roger e Stefani começaram a chorar com medo do fantoche. Mesmo assim Mara continuou a conversar com as crianças, se aproximou do Eduardo e ele ficou bem agitado tentando colocar sua mão na boca da Cuca. Como o Roger e a Stefani ficaram bastante assustados, Mara tirou a fantasia e disse:

- Não precisa chorar, sou eu.

Eles olharam assustados, mas com medo ainda não quiseram se aproximar da fantasia.

- Quem que ser a cuca agora? ( Mara)

Revista eletrônica Zero-a-Seis - $\mathrm{n}^{\circ}$ 22. jun./dez. 2010

Núcleo de Estudos e Pesquisas da Educação na Pequena Infância - CED/UFSC 
- Agora, eu Mala. ( Miguel)

Então Mara vestiu o Miguel com a fantasia e explicou como funcionava. Ele saiu satisfeito assustando seus amigos. Mara chamou algumas crianças para ficarem embaixo do tecido que é o corpo da cuca. Depois de algum tempo a Stefani colocou a roupa e saiu assustando seus amigos. Roger olhava a criança que estava embaixo, manuseando a Cuca, porém mesmo assim se assustava. Mas, para nossa surpresa, após se familiarizar com o fantoche Roger também colocou.. Todas as crianças brincaram com a Cuca, em alguns momentos a disputavam, puxando de um lado para o outro, mediamos a utilização. ( registro do dia .... )

Muitas crianças ficaram eufóricas, querendo tocar, querendo manusear, querendo ser a Cuca, outras porém como o Roger e a Stéfani, ficaram inicialmente com medo, mas logo se familiarizaram com mais uma personagem do Sítio que estaria presente na sala. Neste dia, muitos se divertiram assustando os colegas "sendo" a Cuca. Percebemos que este personagem suscitava na criança diferentes sensações, o medo e o prazer vinham juntos no momento que se relacionam com o personagem.

Buscamos ampliar o repertório artístico e musical de cada um deles partindo de seus conhecimentos prévios e a partir do que eles já conheciam trouxemos elementos novos, através da caixa de música, onde trouxemos músicas novas para cantarmos na roda e também explorando as músicas que eles já conheciam como a música da Cuca que na cena abaixo o Miguel pede para ouvir.

O Miguel falou:

- Ei, Mala. Bota a música da Cuca.

Mara colocou e ele correu para pegar uma toalha que estava na prateleira da sala para por na cabeça e fingiu ser a cuca.

A Lílian olhou pela janela e deu uma gargalhada bem alta, como tem na música e disse:

- ei, Miguel, Lipe apaga a luz.

O Miguel fingiu ser a cuca e ficou pegando seus amigos na sala eles brincaram enquanto a música tocava.

Nós também fingimos pegar eles e eles saiam correndo.

Quando acabou Miguel disse:

- Agora a da Nalizinho.

Perguntei:

- Qual é? Essa eu não sei, me ajuda.

Mexi no som para trocar a faixa.

Revista eletrônica Zero-a-Seis - $\mathrm{n}^{\circ}$ 22. jun./dez. 2010

Núcleo de Estudos e Pesquisas da Educação na Pequena Infância - CED/UFSC 
- Essa não. A outa (Miguel)

Fui trocando e quando começou ele disse:

- Essa.

Então ficamos dançando. (Registro do dia 07/05/08)

Na cena podemos perceber que o Miguel pede a Mara para ouvir a música, sendo que ele já sabe qual música ele quer ouvir dizendo a da Cuca e depois ele fala novamente a da Narizinho, ajudando Mara a encontrar a faixa no CD. E é interessante observarmos a ligação que o menino faz da música da cuca com a toalha na cabeça imitando a personagem.

\subsection{A brincadeira como um direito garantido}

Nosso projeto tinha como um dos principais objetivos estimular a brincadeira, para isso procuramos trazer sempre elementos novos e brincávamos com eles contribuindo para que este momento se tornasse cada vez mais significativo para este grupo.

Alguns autores como Wajscop (2001), Leontiev (1988) e Vigotsky (1984) nos ajudaram a pensar, refletir e entender este momento tão importante da vida da criança, em que o brincar torna-se a atividade principal.

Em um dos nossos dias de intervenção Felipe foi correndo e pegou uma boneca, subiu no cavalinho e colocou a boneca junto com ele. Marcela perguntou para onde ele estava indo, e o menino respondeu: "No médico". Marcela continuou perguntando, o que ele ia fazer lá e logo Felipe respondeu que a boneca estava "dodói” e por isso ele estava levando ela no "carro" com ele. Durante a conversa Felipe disse que era o pai da boneca.

Nesta conversa percebemos que no momento em que Felipe diz ser o pai dela e conta que vai levar sua filha ao médico, está assumindo um outro papel social, como se fosse um adulto. Está trazendo para a brincadeira uma situação do seu meio social, com

Revista eletrônica Zero-a-Seis - nº 22. jun./dez. 2010

Núcleo de Estudos e Pesquisas da Educação na Pequena Infância - CED/UFSC 
certeza, muitas vezes foi levado ao médico pelos seus pais quando estava doente. Ele já faz a relação de que para ir ao médico tem que estar "dodói", como diz o garoto. Segundo Wajscop, (2001, p. 33)

A brincadeira infantil pode constituir-se em uma atividade em que as crianças, sozinhas ou em grupo, procuram compreender o mundo e as ações humanas nas quais se inserem cotidianamente.

Tanto nesta cena aqui trazida como em outras situações, observamos que as crianças realmente agiam de forma que a brincadeira fosse uma atividade que auxiliam as crianças a compreenderem o mundo em que estão inseridas. Assim, como Leontiev afirma, as crianças representam os papéis sociais de forma generalizadora, não possuem o objetivo de reproduzir a pessoa concreta, mas "executar a própria ação como uma relação com o objeto". (1988, p.130)

Foi comum em outros momentos perceber as crianças dando outras funções aos objetos, durante suas brincadeiras. Felipe era uma das crianças que falava muito em dirigir o carro e para isso utilizava diversos objetos. Na cena destacada anteriormente, ele diz que o cavalo é o seu carro, mas também em outros momentos, ao brincar com o pneu, brincar na gangorra, no gira-gira, ele sempre diz que esta dirigindo. Nos contava sempre para onde estava indo: às vezes trabalhar, outras para a praia, para o médico, enfim, estava normalmente dirigindo, independente do objeto que utilizava.

De acordo com Vigotsky (ano) nestas situações o objeto utilizado pela criança (pneu, cavalo, gangorra, etc) permanece com o mesmo significado, porém o sentido sofre uma mudança, o sentido passa a ser o carro. O objeto é ressignificado.

Em muitas das brincadeiras presentes no dia-a-dia das crianças nesse período de estágio, Narizinho e Pedrinho estavam presentes, eram levados para passear no "carro" (cavalo), colocados para dormir, comiam as "comidinhas" imaginárias feitas pelas crianças. Em algumas situações as crianças "trocavam" a fralda desses personagens, conversavam com eles, ou seja, brincavam representando o mundo dos adultos e a forma com que incorporam alguns fatos da realidade.

Revista eletrônica Zero-a-Seis - $\mathrm{n}^{\circ}$ 22. jun./dez. 2010

Núcleo de Estudos e Pesquisas da Educação na Pequena Infância - CED/UFSC 
Brincar é um direito das crianças e como consta no documento elaborado pelo MEC (1995), conforme referimos no início deste trabalho, para garantirmos este direito é necessário que as instituições mantenham os brinquedos disponíveis às crianças em todos os momentos, deixando- os ao acesso das mesas, assim como no cotidiano deve existir momentos longos reservados no cotidiano da creche para que às crianças possam brincar, a organização do espaço também deve ser planejada possibilitando a brincadeira espontânea e interativa. $\mathrm{O}$ mesmo documento ressalta a importância dos adultos brincarem com as crianças e de propor brincadeiras a elas. E foram estes pressupostos que procuramos trazer como orientadores das diferentes atividades que realizamos com as crianças, no desenvolvimento do nosso projeto.

\subsection{Conversando com as crianças}

Estávamos abertas e atentas à participação das crianças em todos os momentos, estimulávamos a linguagem, conversávamos muito com as mesmas, sempre tentando desafiá-las ao novo, ao desconhecido. Estabelecíamos diálogos com as crianças, respeitando-as, reconhecendo-as como crianças, sem sairmos de nosso local de adultas.

Neste exercício de alteridade, procuramos estarmos atentas, às cem linguagens que a criança utiliza, no desejo de que pudéssemos escutar, registrar e representar as vozes e os movimentos destas mesmas.

Narizinho e Pedrinho, personagens do Sítio do Pica-pau Amarelo, nos ajudaram nesses desafios. Foram apresentados à turma, primeiramente em forma de dedoche, e posteriormente foram confeccionados por "Dona Benta" a partir de moldes feitos com o tamanho do corpo das crianças. Os novos amigos da turma, Narizinho e Pedrinho, foram acolhidos com muito carinho por todos, alguns logo memorizaram o nome dos novos colegas, outros demoraram mais.

Peguei um dedoche e disse:

-Duda dá beijinho?

Ela não quis então dei um beijo em seu rosto com a Narizinho (dedoche). Ela me olhou assustada pedi beijo e ela deu com o dedoche, então beijei o dedoche dela.

Revista eletrônica Zero-a-Seis - $\mathrm{n}^{\circ}$ 22. jun./dez. 2010

Núcleo de Estudos e Pesquisas da Educação na Pequena Infância - CED/UFSC 
Ana Clara estava distraída folheando o livro, olhei para ela e disse com o dedoche:

- oi Ana, tudo bem com você? Eu sou a Narizinho.

- Tudo bem?

Ela me olhou, deu uma risada e ficou com o dedinho me mostrando o dedoche. (Registro da Mara do dia 29/05/08)

Nesta cena, usamos dos dedoches para estimularmos o carinho, o afeto, e como de costume, estimulamos a linguagem, convidando a beijarem a Narizinho a conversarem com a personagem. As crianças demonstravam carinho por estes personagens, brincando com eles diversas vezes, e conversavam, se relacionavam com os novos amigos, estabelecendo relações. Abraçavam, beijavam, embalavam, passeavam com eles nos carrinhos, arrastavam no chão, "brigavam", pisavam em cima, levavam ao médico, davam comidas, e conversavam conosco e com seus colegas sobre estes novos amigos. Pedrinho às vezes conversava com as crianças sobre o Sítio, Narizinho pedia abraços e beijos, e assim procuramos estimular diversos aspectos nas crianças como a linguagem, o diálogo, a curiosidade, a imaginação a se expressarem de diversas formas.

Ao nosso ver, é imprescindível que educadores instaurem meios para os diálogos acontecerem, não só verbais mas também os gestuais e afetivos.

Nas conversas que estabelecíamos com as crianças buscávamos sempre trazer elementos novos. Reconhecíamos e respeitávamos as especificidades de cada criança desta turma, algumas já falavam, outras pronunciavam apenas algumas palavras, outras ainda não falavam, porém nos comunicávamos com todas.

Segundo Ferreira (2002, p.82)

Existem diferenças entre a fala de uma criança e de outra, pois cada uma teve oportunidades diferentes de estar em diversas situações sociais. Além disso, cada uma convive com adultos e crianças diferentes, que interagem com elas de diferentes formas, prestam atenção e interpretam de formas diversas suas falas, fornecem-lhes modelos diversos de imitação.

Foi tendo consciência destes aspectos e respeitando estas especificidades e o tempo, de cada uma, que conversávamos diariamente com todas as crianças. A mesma autora

Revista eletrônica Zero-a-Seis - $\mathrm{n}^{\circ}$ 22. jun./dez. 2010

Núcleo de Estudos e Pesquisas da Educação na Pequena Infância - CED/UFSC 
segue afirmando que é na interação da criança com os demais que a mesma vai desenvolvendo a fala.

Algumas crianças costumavam "jogar” com as palavras, como por exemplo Miguel, nas cenas destacadas à baixo:

- Qué peixe? (Miguel)

- Peixe que delícia, eu adoro peixe? (Mara)

- Espera ta quente. (Miguel)

Mara esperou, enquanto isso ele ficou mexendo nas loucinhas como se estivesse fazendo a comida, depois ele ofereceu novamente.

- Qué camalão? (Miguel)

A Marcela ouviu a conversa e disse:

- Camarão eu adoro. Eu quero.

- Macalão. (Miguel)

- O que? É macarrão ou camarão? (Marcela)

Miguel sorriu e ficou alguns segundos pensando, logo respondeu:

- Camalão. (Registro do dia 28/05/08)

- Oh, Macia. (Miguel)

- Meu nome não é Márcia, é Mara. (Marcela)

- Não é, é Macela. (Miguel)

- Não é, é Mala. (Nicolas)

O Miguel disse apontando para a Marcela:

- Ela é Mala.

- Não. É Macela. (Nicolas)

A Marcela olhou e disse:

- Eu sou a Marcela, ela é a Mara.

- Mala. (Miguel)

$\mathrm{O}$ menino continuou brincando fingindo não ter entendido. (Registro do dia 06/05/08)

Nos dois episódios destacados, Miguel brinca com o som das palavras, no primeiro, ora fala "macalão", ora fala "camalão", sendo duas palavras com sons semelhantes. Ele brinca nos confundindo, porém no diálogo que mantivemos com ele naquele momento pronunciávamos as palavras diferenciado-as e incentivando o garoto a pronunciá-las novamente. No segundo episódio, a mesma criança brinca com os nossos nomes, trocandoos, chamando Marcela de Mara e Mara de Marcela, trazendo ainda um terceiro nome também iniciado com a letra $\mathrm{M}$, Márcia. Nicolas também participou desta conversa

Revista eletrônica Zero-a-Seis - nº 22. jun./dez. 2010

Núcleo de Estudos e Pesquisas da Educação na Pequena Infância - CED/UFSC 
ajudando a diferenciar os nomes, de nós duas. Entramos neste "jogo" com as crianças, mas não deixamos de nos identificarmos corretamente.

Estes foram apenas alguns dos episódios que aconteceram das crianças brincando com o som das palavras, percebemos que elas brincavam realmente, como se estivessem brincando com outro brinquedo qualquer. Elas experimentavam combinações de palavras e exploravam regras de linguagem (Ferreira, 2002 p.82 ).

Ao conversarmos com as crianças instigávamos a pensarem, a refletirem, a pronunciarem "novas" palavras. As crianças aprendem a usar as palavras para pensarem, pois a "linguagem possibilita pensarmos sobre mais coisas, nos dá acesso a algo que não está concretamente presente, mas pode ser pensado e elaborado enquanto palavra, enquanto conceito. (...) Falar e pensar, portanto, não se aprende sozinho, mas na interação com outros"' (Ferreira, 2002 p.18).

Dialogar com as crianças, buscar meios de comunicação e de interação com elas, foi uma experiência "deliciosa", muito agradável. Desafiar as crianças e incentivá-las a se comunicarem, foi também para nós, um desafio, que aconteceu naturalmente. Buscamos valorizar a fala, e a forma de todos se comunicarem, e em algumas situações procuramos incentivá-las a conversarem entre si, ajudando e mediando algumas conversas

\subsection{A relação entre creche e família}

Durante o período de observação e até mesmo na regência desta turma, nos chamou atenção o fato de os pais terem livre acesso dentro de sala, não só no momento de entrada e saída, mas também nos horários das atividades e alimentação.

Consideramos relevante o acesso que os pais têm de participarem e interagirem com seus filhos na creche, pois entendemos que essa abertura é muito positiva, tanto para as educadoras como também para as crianças que se sentem seguras dentro do local em que ficam muitas vezes a maior parte do seu dia. Maistro (2004) destaca que é fundamental entendermos que na relação entre família e a instituição de Educação Infantil existe uma função de complementaridade, pois ambas possuem distintas funções de educar e cuidar. Concordando com a autora, acreditamos que essa relação só poderá ser alcançada através

Revista eletrônica Zero-a-Seis - nº 22. jun./dez. 2010

Núcleo de Estudos e Pesquisas da Educação na Pequena Infância - CED/UFSC 
de uma aliança, a ser tecida no dia-a-dia das instituições, entre as profissionais das creches e as famílias das crianças. Também neste sentido, Tiriba, 2001 destaca que:

Um caminho de aproximação entre creche e famílias tem sido o de mexer na organização dos espaços e das rotinas, de modo a favorecer a inserção efetiva das famílias. São inúmeras as possibilidades, algumas já vivenciadas e aprovadas. Uma delas é abrir os portões e as portas para os pais, especialmente nos momentos em que vêm trazer e buscar seus filhos, facilitando o contato com os profissionais, possibilitando que tenham acesso a todos os espaços (salas, berçários, pátios, parques, refeitórios, banheiros, corredores). (TIRIBA, 2001, p. 76-77).

Analisamos que a entrada e a participação dos pais na creche ocorrem de forma natural, e isso nos mostra que tanto a instituição quanto as professoras estão atentas à importância da presença da família no processo educativo. A partir disso, tentamos perceber as necessidades das crianças e consideramos a presença dos pais na sala de extrema importância para o nosso trabalho, por isso procuramos valorizar esses momentos, buscando conhecer ainda mais cada criança. Abaixo, destacamos algumas cenas em que os pais estavam participando com seus filhos em diferentes momentos na creche.

A mãe do kauan entrou na sala e se escondeu.

- Kauan quem chegou? (Marcela)

O menino olhava para todos os cantos da sala e não encontrava ninguém além de seus colegas, olhava Marcela ansioso aguardando o que ela ia dizer.

- Não foi ninguém Kauan? (Marcela)

Ele continuava procurando, então começou a olhar fixo para a Mara, pois a mãe dele estava escondida atrás dela.

- Eu acho que veio alguém cantar parabéns pra ti, quem será? (Marcela)

O menino que estava sentado levantou e foi em direção a Mara.

- O que foi Kauan? Por que estás me olhando? (Mara)

Neste momento a mãe dele apareceu, e ele foi correndo dar um abraço, chamava sua mãe para mostrar tudo, os brinquedos, os colegas... (Registro do dia 30/04)

Enquanto pintavam aparecia a Dona Benta, a Emília, alguns personagens. A mãe do Gustavo chegou e ficou olhando o menino pintar, sentou ao lado dele e ficou esperando, pois ele não queria ir embora. (Registro do dia 07/05)

Demos um pouco de massinha, para o Eduardo, que tentava fazer diversos movimentos com a mão, apertava a massinha e olhava para a sua mão sorrindo. Neste momento sua mãe chegou, Eduardo se agitou no carrinho, ela demonstrou ter ficado bem contente em ver seu filho com a massinha, sentou em uma

Revista eletrônica Zero-a-Seis - $\mathrm{n}^{\circ}$ 22. jun./dez. 2010

Núcleo de Estudos e Pesquisas da Educação na Pequena Infância - CED/UFSC 
cadeira com as demais crianças e colocou o Eduardo em seu colo, incentivando o menino a mexer na massinha, batendo as mãos, amassando, fazendo diversos movimentos, o menino dava gargalhada. (Registro do dia 05/05)

O pai do Kauan estava junto conosco neste momento e se divertia vendo as crianças pintando, conversando, trocando de tinta, pegando o pincel do amigo, pintando com dois pincéis, pintando as unhas. Tudo que o kauan fazia ele chamava o pai para mostrar.

(...) O pai do kauan ao olhar algumas crianças ajudando a carregar a cadeira com dificuldade perguntou a eles se queriam ajuda, porém eles não quiseram e continuaram carregando.

- kauan ajuda também a levar as cadeiras (pai do Kauan).

Kauan é uma das crianças menores da turma, e a cadeira para ele era muito pesada, porém ele tentava levar arrastando. O pai dele o ajudou a levar, e logo que ele deixou a cadeira na sala, o menino já correu para pegar outra. (Registro do dia $06 / 05$ )

Nas cenas que foram destacadas, podemos perceber como a presença dos familiares (a mãe do Kauan, a mãe Gustavo e a mãe do Eduardo) aconteceu de modo sutil e ao mesmo tempo muito participativa, pois elas respeitaram o momento das crianças e se dispuseram a esperar, como no caso da mãe do Gustavo e até mesmo, como a mãe do Eduardo sentou com seu filho e o incentivou a participar naquele momento.

$\mathrm{Na}$ última cena, o pai do Kauan se mostrou um pai presente e participativo, ou seja, ele acompanhou algumas vezes as atividades, mas em sua face víamos um olhar de satisfação, sempre incentivando seu filho a participar das atividades de modo integral e a relacionar-se com as demais crianças, se colocando a disposição em nos ajudar no que fosse necessária. Acreditamos que essa presença do pai na instituição foi muito importante para o Kauan, assim como para as outras crianças.

Percebemos que a presença da mãe do Eduardo acontecia muitas vezes pela preocupação que ela tinha com seu filho. Observamos que a partir da conversa com as educadoras a mãe de Eduardo, de forma sutil, tentava participar dos momentos de seu filho na creche estimulando-o a participar das brincadeiras, a explorar melhor o espaço da sala, parque, entre outros, juntamente com as outras crianças. Na cena, podemos entender melhor de que maneira isso acontecia na instituição:

A mãe do Dudu pegou o menino e começou a colocá-lo em diversos espaços na sala, até mesmo sentado no cavalinho com o auxílio dela. O menino tentava

Revista eletrônica Zero-a-Seis - $\mathrm{n}^{\circ}$ 22. jun./dez. 2010

Núcleo de Estudos e Pesquisas da Educação na Pequena Infância - CED/UFSC 
olhar para todos que passavam ao redor dele, dava várias risadas. (Registro do dia $05 / 05)$

$\mathrm{Na}$ cena, podemos verificar a preocupação da mãe do Eduardo quanto à sua participação, juntamente com as outras crianças, nas diversas atividades com a turma. Mas destacamos que a aproximação entre esta mãe e as educadoras foi muito importante no processo educativo do Eduardo. Como vimos, Maistro, 2004:

(...) é importante ressaltar a necessidade da complementaridade entre a família, o meio e a instituição. Todos são fundamentais no ato educativo junto às crianças pequenas. Deste modo, o (a) educador (a) é sem dúvida um dos mediadores principais no desencadear dessa inter-relação, reconhecendo a família como uma parceira ativa e essencial na educação infantil. (MAISTRO, 2004, pg. 100)

Conforme aponta a autora, este foi o caminho para criarmos alternativas de intervenção, partindo das necessidades de cada criança para alcançarmos um trabalho mais significativo com elas. Foi assim que procuramos incluir o Eduardo nas diferentes atividades, estimulando-o a participar de todos os momentos, juntamente com as outras crianças.

Outro aspecto relevante observado, foi à interação das crianças com seus pares e/ou com os adultos, que acontecia o tempo todo. De uma forma ou de outra, estavam o tempo todo se relacionando com alguém, nos chamou a atenção que, mesmo as crianças pequenas, já têm preferências, já possuem mais afinidade com determinados colegas. Nesta turma, de uma forma geral, as crianças demonstram o tempo todo um carinho especial pelo Eduardo, chamado carinhosamente de Dudu. Este menino, por possuir uma paralisia cerebral, tem determinadas dificuldades em desenvolver a parte motora e a fala.

Foram diversas as situações em que pudemos registrar o carinho e o cuidado das crianças com ele, como por exemplo, no dia em que distribuímos os dedoches:

Miguel pegou o seu dedoche e tentou colocar no dedo do Dudu, enquanto tentava colocar dizia:

- Assim Dudu, abi a mão.

Como não conseguiu, Mara o auxiliou. Quando Mara colocou o dedoche no dedo do Eduardo, Miguel sorriu e disse:

- Viu Dudu, é o Pedinho.

Revista eletrônica Zero-a-Seis - $\mathrm{n}^{\circ}$ 22. jun./dez. 2010

Núcleo de Estudos e Pesquisas da Educação na Pequena Infância - CED/UFSC 
Logo, saiu e foi brincar. (Registro do dia 28.05.2008)

Neste episódio podemos perceber o carinho do Miguel em relação ao Eduardo. Todos estavam brincando com os dedoches e somente ele não estava, então o menino diante dessa situação, emprestou o seu dedoche ao amigo e se esforçou em tentar colocá-lo. Talvez tenha feito isso, pois sabia da dificuldade do Eduardo. Esta foi apenas uma das vezes em que Miguel demonstrou este carinho por Eduardo, e assim como ele, outras crianças, também assim agiam.

No início do estágio de intervenção não sabíamos quis eram ao certo as limitações do Eduardo. No primeiro dia de intervenção pensamos o fato de o Dudu estar presente na roda já estava participando daquele momento, mas não nos demos conta de que deveríamos ter entregado ao Eduardo o dedoche para que ele pudesse manusear também. Só fomos perceber isso quando observamos o Miguel tentando colocar o seu dedoche no Eduardo. Após este dia buscamos envolvê-lo sempre em todos os momentos.

No parque, Eduardo não participava muito das brincadeiras e interações com as outras crianças. Aos poucos, fomos tentando proporcionar ao menino a vivência de experiências diferentes para que ele pudesse se relacionar com as crianças no parque, pois na maioria das vezes ele ficava no carrinho ou no colchonete. Quando colocávamos o menino em lugares que ele não costumava ir, como no escorregador, sentado na areia, "andando" pela calçada, as outras crianças se aproximavam para ver, e demonstravam a sua alegria por estarem compartilhando estas vivências com o amigo.

$\mathrm{Na}$ cena em destaque podemos analisar uma situação interessante ocorrida no parque.

Marcela ficou andando com o menino fazendo com que ele tentasse andar pela calçada. Depois o colocou no escorregador, e o sentou na areia do parque para brincar. Ana Clara se aproximou, sentou ao lado do menino e trouxe brinquedos para brincar com ele, ela fingia fazer comidinha e oferecia para o menino a colher com a areia. $\mathrm{O}$ menino ria bastante e se mexia muito, tentando pegar os brinquedos, Felipe quando passava por ali entregava algo para Eduardo. (Registro do dia 20.05. de 2008)

Revista eletrônica Zero-a-Seis - $\mathrm{n}^{\circ}$ 22. jun./dez. 2010

Núcleo de Estudos e Pesquisas da Educação na Pequena Infância - CED/UFSC 
Nesta situação que destacamos, ao colocarmos Eduardo sentado na areia do parque, vimos que logo algumas crianças se aproximaram naturalmente dele. Ana Clara sentou próxima do menino e trouxe alguns brinquedos para que pudessem brincar. Brincava com Eduardo da mesma forma com que brinca com as outras crianças. Cardoso (2007, p.90) afirma que é "interessante observarmos como as crianças constroem conceito de normalidade quando convivem com a possibilidade de produzir o que, para nós adultos, seria diferente ou deficiente".

A identidade social anormal não se caracteriza pela simples presença de uma diferença, mas pelas conseqüências que tais diferenças acarreta na participação desse sujeito na construção coletiva de sobrevivência e reprodução de diferentes agrupamentos sociais, em diferentes momentos históricos. (Cardoso apud Bueno, p.94).

Como podemos perceber, de acordo com este autor, a "anomalia", caracteriza-se muitas vezes pelo fato de como nos relacionamos com este que consideramos "diferente", muitas vezes o que lhe faz ser diferente é a forma como nos relacionamos com ele. Ao sabermos que íamos ter que "trabalhar" com o Dudu, ficamos com receio, por pensarmos que não tínhamos o suporte teórico e a prática necessária para desenvolvermos um projeto significativo para o desenvolvimento desta criança. Segundo Cardoso (2007)

\begin{abstract}
A relação do professor com a criança deficiente se torna distinta da relação com as outras crianças, pois permanece a idéia de que é preciso se especializar para dar conta do trabalho com deficiente, além de se instrumentalizar para compreender todo o arsenal de termos médicos trazidos pelos serviços especializados aos quais o deficiente é encaminhado, ou dos quais veio encaminhado para o ensino regular. (CARDOSO \& CUNHA, 2007 p.87)
\end{abstract}

Buscamos incluir este menino em todas as experiências e propostas que trazíamos à turma, e a respeitá-lo, assim como as outras crianças. Acreditamos que a mediação do professor é fundamental no processo de inclusão, na tentativa de integrar todas as crianças de forma a lhes dar suporte para que possam se sentir como parte da instituição, sendo respeitados da maneira como eles o são. Afinal, a "educação fala no 'diferente', assim como nos projetos pedagógicos e nos planos de trabalho, destacando que cada criança é

Revista eletrônica Zero-a-Seis - $\mathrm{n}^{\circ}$ 22. jun./dez. 2010

Núcleo de Estudos e Pesquisas da Educação na Pequena Infância - CED/UFSC 
única, tem seu próprio ritmo de desenvolvimento e este deve ser respeitado" (CARDOSO \& CUNHA, 2007 p. 88).

\section{Que delícia escutar e conversar com as crianças.}

\section{- Na hora do lanche}

- O que foi Miguel? (Marcela)

- To comendo tudo.

- Que bom amigo, se quiseres mais é só pegar lá. (Marcela)

- Ta bom, mas não acabou ainda.

(Registro do dia 28/05)

\section{- Brincando com as bonecas}

Felipe foi correndo e pegou uma boneca, subiu no cavalinho e colocou a boneca junto com ele. Marcela perguntou:

- Vais aonde, Lipe?

- No médico.

- Fazer o quê?

- Ela tá dodói, vo no caoo.

- No carro? Que legal vai rápido então.

(Registro do dia 30/05)

\section{- Caixa surpresa}

- Vamos sacudir a caixa? Será que faz barulho? (Marcela perguntou)

Marcela sacudiu a caixa e não fez barulho então "Lipe" falou:

- Não tem nada.

- Será Lipe? Será que a dona Benta mandou a caixa vazia?

- É. (Miguel)

- Poxa, mas aí eu vou ficar triste. Eu acho que ela mandou alguma coisa do sítio.

- A coba. (Nicolas)

- A cobra? Será?

Então chamei as crianças uma de cada vez para espiar o que tinha na caixa. Maria Eduarda fazia força para abrir a caixa, estava agoniada querendo ver, primeiro Marcela colocou um bracinho da Narizinho para fora e pedia para eles dizerem o que tinha ali, em seguida ela mostrou outras partes do corpo da boneca. Então Gabriela disse:

- Uma boneca.

- Será, Gabi?

A menina afirmava com a cabeça.

Revista eletrônica Zero-a-Seis - $\mathrm{n}^{\circ}$ 22. jun./dez. 2010

Núcleo de Estudos e Pesquisas da Educação na Pequena Infância - CED/UFSC 
Quando Marcela tirou a Narizinho da caixa, a maioria das crianças sorriram e Ana Clara e Nicoli batiam palmas, Miguel foi abrir a caixa para ver se tinha mais alguma coisa. Nicolas berrou:

- O bicho, o bicho.

- É um bicho Nic?

- é ...

- Não Nicolas, é a Narizinho, a amiga da Emília.

- Narizinho? (falou e colocou o dedo no nariz dele).

As crianças davam "oi" para a Narizinho e Eduarda, Nicoli, Lipe, levantaram para dar um beijo na nova amiga da sala. Ana Clara levantou-se e foi abraçá-la.

- Marcela perguntou: Ô Narizinho, tinha mais alguém contigo na caixa?

Narizinho fez que sim com a cabeça, então abri a caixa e Miguel logo foi olhar.

- O que tem aí amigo? (Marcela)

- Oto boneco.

- Quem é esse? (Miguel)

- Marcela falou e tirou o boneco da caixa, dizendo:

- Esse é o primo da Narizinho, o Pe...

- Dinho. (Nicolas completou)

- O Pedrinho, quem vai dar um abraço no amigo? (Marcela)

As crianças se levantaram para abraçar o Pedrinho.

(registro do dia 05/05)

\section{- Colocando a mão na massa...}

\section{Massinha criando muitas formas!}

Eles brincaram durante um bom tempo com a massinha, alguns não permaneceram sentados manuseando a massinha por muito tempo, como o Kauan, Érica, Pedro, Gabrielli, Miguel e Nicolly. Kauan ficou brincando com os livros, os carrinhos, entre outros. O Miguel sentou perto de Mara com um livro na mão e disse:

-Mala, senta, senta. Vai começa a histólia.

Ah, é. Então tá. Pode começar a contar Miguel. (Mara)

- Ele folheou algumas páginas e depois disse:

- olha o que tem aqui. (se referindo a imagem)

- uva. (Mara)

É. (Miguel)

- Acabo. (Miguel)

Ele levantou foi até o varal dos livros, pegou outro livro, sentou-se e disse:

- Vou conta outra histólia.

- Mara pergunta: posso convidar o Pedrinho para ouvir?

- pode.

- então, Mara sentou o Pedrinho do lado onde eles estavam e Ėrica e Gabrielli sentaram junto para ouvir a história.

(registro do dia 05/05)

Revista eletrônica Zero-a-Seis - $\mathrm{n}^{\circ}$ 22. jun./dez. 2010

Núcleo de Estudos e Pesquisas da Educação na Pequena Infância - CED/UFSC 


\section{Tintas, muitas formas e cores!}

(...) Os potes colocados sobre a mesa eram de uso coletivo, de vez em quando trocávamos um pouco o local onde estavam os potes para que as crianças pudessem utilizar outras cores. Miguel estava usando o vermelho, pois era a tinta que estava próxima dele, depois de usar diversas vezes aquela tinta falou:

- Agora eu quero a de menina.

- Que cor que você quer? (Marcela)

- A de menina. - respondeu Miguel apontando para a cor rosa.

- A rosa?

- A de menina. (Repetiu apontando para a rosa)

- Rosa é de menina? (Marcela)

- É. (Miguel)

- E vermelho é de que? (Marcela)

- É de... Eu quero a rosa de menina. (Miguel)

(Registro do dia 06/05)

\section{- Cantando e dançando com os pequeninos!}

- O Miguel falou.

- ei, Mala. Bota a música da Cuca.

- Mara colocou o CD e ele correu para pegar uma toalha que estava na prateleira da sala e colocou na cabeça e fingiu ser a Cuca.

- a Lílian olhou pela janela e deu uma gargalhada bem alta e disse:

- ei, Miguel, Lipe apaga a luz.

- o Miguel fingiu ser a Cuca e tentou pegar seus amigos na sala, eles ficaram brincando enquanto a música tocava.

Mara e Marcela também fingiram pegar eles e eles saiam correndo.

Quando acabou Miguel disse:

- agora a da Nalizinho.

- Mara perguntou, qual é? Essa eu não sei, me ajuda.

- Mara mexeu no som para trocar a faixa.

- essa não. (Miguel)

- a outa. (Miguel)

- Mara foi trocando e quando começou ele disse: essa.

- então ficamos dançando.

(Registro do dia 07/05)

\section{- Dando outros significados aos objetos e brinquedos!}

Foram confeccionadas 10 (dez) garrafas, cada criança ajudou um pouquinho. Podemos perceber que o que mais chamou a atenção deles foi a cor do gliter e da purpurina.

Gabrielli disse:

Revista eletrônica Zero-a-Seis - $\mathrm{n}^{\circ}$ 22. jun./dez. 2010

Núcleo de Estudos e Pesquisas da Educação na Pequena Infância - CED/UFSC 
- é amalela.

- e essa que cor é? (Mara)

- azul. (Gabriela)

- E essa? (Mara)

Gabriela, Érica e Eduarda ficaram quietas, então Mara disse:

- é vermelha.

- vimelha, repetiu Érica e Gabrielli.

(...) Logo depois Gabrielli sentou no colchonete, onde estavam Mara, Stefani e a Eduarda e a Marcela ficou comentando a cor do brilhinho no fundo da garrafa e mexi para vermos o brilho se misturar com a água e Gabrielli disse:

- é ceveja.

- cerveja? (Mara)

- é. (Gabrielli)

- Eu não quero, eu não gosto de cerveja, gosto de suco. (Mara)

A menina pegou outra garrafa e disse

- É coca. (Gabrieli)

Mara fingiu estar tomando. A menina sorriu e ofereceu outra garrafa.

- É veneno. (Gabrieli)

- Ai, não, veneno, não. Tem suco? (Mara)

Então a menina deu outra garrafa dizendo ser suco.

- Que delícia, hum. Está muito bom. (Mara)

(registro do dia 19/05)

$\mathrm{O}$ Felipe e o Nicolas depois que estavam prontas às garrafas pegaram uma a uma e colocaram deitadas no colchonete e começaram a se jogar. Inicialmente Mara e Marcela não entenderam o que eles queriam, então Marcela perguntou:

- o que é isso Felipe?

- piscina. (Felipe)

- é uma piscina, que legal. E o que estas fazendo? (Marcela)

- megulhando. (Felipe)

(registro do dia 19/05)

\section{- Observando e aprendendo com a natureza}

Miguel encontrou um monte de formigas em uma árvore, elas subiam e desciam com pedaços de folha, o menino ficava olhando e acompanhando o trajeto delas, Marcela se aproximou para ver o que fazia Miguel estar ali tanto tempo. Logo, Miguel disse a Marcela: - A fomiga, ta levando a folhinha.

- É verdade Miguel, e vistee como estão ficando as folhas dessa árvore? (Marcela)

O menino se esticou para ver, nesse momento todas as crianças estavam ao redor observando.

- Ta furado. (Felipe)

- É amigo, elas estão comendo as folhas da árvore. (Marcela)

Revista eletrônica Zero-a-Seis - $\mathrm{n}^{\circ}$ 22. jun./dez. 2010

Núcleo de Estudos e Pesquisas da Educação na Pequena Infância - CED/UFSC 
Marcela ficou alguns minutos com as crianças conversando sobre as formigas. Marcela afastou-se para conversar com professora. Quando ela olhou. Algumas crianças estavam pisando em todas as formigas. Marcela perguntou, por que estavam fazendo isso? As crianças não responderam e continuaram pisando nas formigas.

- Coitadinha da formiga, ela é boazinha, não mata ela. (Marcela)

- A mãe vai chorar, né? (Felipe)

- É a mãe dela vai ficar triste. (Marcela)

Em seguida, pararam e continuaram acompanhando o trajeto delas. Miguel disfarçava e de vez enquanto matava algumas formigas.

(registro do dia 12.05)

\section{- Tchau, jacaré!}

Mara e Marcela estavam indo embora, Miguel as chamou, ele estava no banheiro. Marcela foi ver o que ele queria.

- Limpa o meu bumbum, Macela. (Miguel)

- Limpo, o que você fez? (Marcela)

- Fiz um jacaré. (Miguel)

- Um jacaré? (Marcela)

- É ele tem rabo. (Miguel)

Marcela após ajudar o Miguel, foi dar descarga e Miguel não deixou. Chamou um colega da outra turma que também estava no banheiro para ver o "jacaré" $\mathrm{O}$ menino veio e também ficou olhando para o que o Miguel tinha feito.

- é o jacaré, visse o rabo dele? (Miguel)

- Poxa, que legal, parece com um jacaré Miguel? (Marcela)

- É. (Miguel)

- Vamos mandar ele embora agora? (Marcela)

- Dá tchau pra ele Macela. (Miguel)

Miguel, seu colega e Marcela deram tchau para o "jacaré" e logo depois Marcela foi embora. (registro do dia 12.05)

\section{- Aprendendo com as crianças!}

Hoje trouxemos o fogão e a geladeira para eles utilizarem na casinha e pedimos para pintarem o fogão com tinta guache no parque. O Miguel, assim que eles terminaram de pintar, disse:

- Macela, tem que colocar no sol.

- No sol, Miguel? (Marcela)

- é pra secar. (Miguel)

(Registro do dia 19/05)

\section{Conclusão}

Revista eletrônica Zero-a-Seis - ${ }^{\circ}$ 22. jun./dez. 2010

Núcleo de Estudos e Pesquisas da Educação na Pequena Infância - CED/UFSC 
A vivência deste estágio foi uma experiência relevante na nossa trajetória acadêmica, pois pudemos sentir na prática muita das questões que estudamos durante nossos quatro anos de formação, mas especificamente nesse último ano. Assim, estávamos ansiosas para esta última vivência, enquanto acadêmicas.

Apesar de termos realizado uma observação no semestre anterior na mesma creche, nossa experiência neste ano foi diferente. Tínhamos crianças na turma que não conhecíamos ainda, assim como outras profissionais. Fomos muito bem acolhidas, e de certa forma as professoras nos deixaram à vontade para desenvolvermos o nosso projeto tendo como foco as crianças e os desejos de conhecimento do mundo.

Este período de estágio foi muito significativo para nossa formação como futuras educadoras, pois nos confrontamos com situações onde pudemos perceber a importância da presença da família no contexto da creche, de estarmos atentas às especificidades de cada criança, de nos colocarmos no lugar delas, de nos "alfabetizarmos nas diferentes linguagens", da flexibilidade do planejamento, de que educar e cuidar se constituem como práticas indissociáveis, de ampliar o repertório das crianças, de trabalhar o lúdico, a fantasia, de estimular e valorizar as brincadeiras, a linguagem, entre outras coisas.

Planejamos diversos momentos, pensando no dia que faríamos cada um deles, porém sabíamos da importância do planejamento ser flexível, pois teríamos que contar com alguns imprevistos, como questões de intempéries, de respeitar o tempo de cada criança, como quaisquer outros que podiam acontecer.

Era comum encontrarmos pais e mães presentes na sala, durante à tarde, observando e/ou interagindo com as crianças. O que consideramos de extrema importância para que eles participassem ativamente do desenvolvimento e do aprendizado dos seus filhos e pudessem conhecer um pouco mais o ambiente em que as crianças (seus filhos e filhas) passam muitas vezes a maior parte do dia.

Durante a realização do projeto, um dos grandes desafios para nós foi "incluirmos" o Dudu nas diversas atividades pensadas para as crianças. Iniciamos com receio, pois não tínhamos um suporte teórico para lidar com esta situação. Porém, durante o estágio, fomos conhecendo melhor esta criança e pensando/buscando/experimentando alternativas e meios

Revista eletrônica Zero-a-Seis - nº 22. jun./dez. 2010

Núcleo de Estudos e Pesquisas da Educação na Pequena Infância - CED/UFSC 
de incluí-la nos diversos momentos propostos. Aprendemos muito ao observar o relacionamento das outras crianças com ele, e bem como o de sua mãe que sempre estava presente conversando conosco e estimulando o menino.

A nossa experiência convivendo com o Dudu neste período, observando-o sozinho e na interação com os demais, atentas a cultura que essas crianças produziam ao se relacionarem, foi um dos aspectos mais relevantes para nós neste estágio. Percebemos que, ao contrário do que pensávamos, conseguimos incluí-lo, e isso não foi tão difícil, afinal desde o início nosso discurso era respeitar as especificidades de cada criança e isso acreditamos que conseguimos fazer.

Percebemos que a brincadeira realmente é algo que se aprende e que se transforma e se cria, e que ao trazermos elementos novos para as crianças, conseguimos instigá-las e ampliar o repertório cultural delas. Todos os momentos, a nosso ver, foram significativos, tanto para as crianças como para nós. Conseguimos por meio deste estágio relacionar a teoria com a prática, passando a questionar alguns autores e confirmar o que outros dizem, em um diálogo constantemente mediado pela práxis.

\section{Referências}

CAMPOS, Maria Malta e Fúlvia Rosemberg. Critérios para um atendimento em creches que respeite os direitos fundamentais das crianças. Brasília: MEC/SEF/COEDI, 1995

CARDOSO, Beatriz Angélica Ancântara \& CUNHA, Eliana Briense Jorge. Preconceitos a serem demolidos superando a patologização das diferenças: os comprometimentos fisiológicos impedem a produção das culturas infantis? In: FARIA, Ana Lúcia Goulart de ; MELLO, Suely Amaral (org). Territórios da infância: linguagens, tempos e relações para uma pedagogia para as crianças pequenas. Araraquara: Junqueira e Marin, 2007. v. 1 .

CARVALHO, Mara I. Campos \& RUBIANO, Márcia R. Bonagamba. Organização do Espaço em Instituições Pré-Escolares. In: OLiVEIRA, Zilma de Moraes Ramos de (org). Educação Infantil: muitos olhares.. São Paulo: Cortez, 1994.

FREIRE, Paulo. Pedagogia da Autonomia : Saberes Necessários à Prática Educativa. São Paulo:. Paz e Terra, 1996.

Revista eletrônica Zero-a-Seis - $\mathrm{n}^{\circ}$ 22. jun./dez. 2010

Núcleo de Estudos e Pesquisas da Educação na Pequena Infância - CED/UFSC 
FERREIRA, Maria Clotilde Rosseti \& GUIMARÂES, Laudicéia \& COSTA, Edna Ap. A. da. Conversas para aprender a conversar. In: FERREIRA, Maria Clotilde Rosseti \& MELLO, Ana Maria \& VITORIA... (orgs). Os fazeres na Educação Infantil. 5. ed. São Paulo: Cortez, 2002.

GALLARDINI, Anna Lia. Pesquisa sobre o espaço coletivo como ambiente de desenvolvimento infantil - texto apresentado no IV Simpósio Latino Americano de atenção à criança de 0 a 6 anos/ II Simpósio Nacional de Educação Ifantil. Brasília, 1996. IN: GUIMARÃES, Daniela \& LEITE, Maria Isabel. A pedagogia dos pequenos: uma contribuição dos autores italianos. Caxambu: ANPEd, 1999. p. 171-171.

GUIMARÃES, Daniela \& LEITE, Maria Isabel. A pedagogia dos pequenos: uma contribuição dos autores italianos. In: 22a. Reunião Anual da ANPEd, 1999, Caxambu: ANPEd, 1999. p. 171-171.

LEONTIEV, Aléxis N. Os princípios psicológicos da brincadeira pré-escolar. In: Vigotsky, L. S. Linguagem, desenvolvimento e aprendizagem. São Paulo: Ícone- EDUSP, 1988. Tradução de Maria da Penha Villalobos.

MAISTRO, Maria Aparecida. Construindo algumas alternativas de ação no trabalho com as famílias. In: PMF. Secretaria Municipal de Educação - SME. Divisão Educação Infantil. Caderno de Formação/ Divisão de educação Infantil. Florianópolis: Prelo, 2004.p.95100 .

MELLO, Suely Amaral. Não fazer das palavras um atalho ao conhecimento. In: FARIA, Ana Lúcia Goulart de ; MELLO, Suely Amaral (org). Territórios da infância: linguagens, tempos e relações para uma pedagogia para as crianças pequenas. Araraquara: Junqueira e Marin, 2007. v 1.

OSTETTO, Luciana Esmeralda. Planejamento na educação infantil: mais que a atividade, a criança em foco. In: Campinas- SP: Papirus, $\overline{2000})$. (Org.) Encontros e encantamentos na educação infantil.

PEREIRA, Teresa. Curiosidade, uma ferramenta para construção do conhecimento. Disponível em: http://www.ndpc.com.br/pag html/Artigo curiosidade.htm. Acesso em: 28 de maio de 2008.

TRISTÃO, Fernanda C. Ser professora de bêbes: um estudo de caso em uma creche conveniada. 2004. Dissertação (Mestrado em Educação).

VIGOTSKI, L. S. A formação social da mente: o desenvolvimento dos processos psicológicos superiores. São Paulo: Martins Fontes, 1984.

Revista eletrônica Zero-a-Seis - $\mathrm{n}^{\circ}$ 22. jun./dez. 2010

Núcleo de Estudos e Pesquisas da Educação na Pequena Infância - CED/UFSC 
WAJSKAOP, Gisela. Brincar na pré-escola. São Paulo: Cortez, 1995. (Col. Questões da nossa época; vol.48)

Revista eletrônica Zero-a-Seis - $\mathrm{n}^{\circ}$ 22. jun./dez. 2010

Núcleo de Estudos e Pesquisas da Educação na Pequena Infância - CED/UFSC 